\title{
Vitamin D receptor gene polymorphisms and susceptibility for primary osteoarthritis of the knee in a Latin American population

\author{
Norma Celia González-Huerta', Verónica Marusa Borgonio-Cuadra', Eugenio Morales-Hernández², \\ Carolina Duarte-Salazar ${ }^{3}$ and Antonio Miranda-Duarte ${ }^{1 *}$ (D)
}

\begin{abstract}
Background: Primary Osteoarthritis (OA) of the knee is a multifactorial disease that has an important genetic component, and several genes have been associated with its development. The vitamin $D$ receptor has a role in skeletal metabolism that suggests a relationship with $\mathrm{OA}$. The aim of this study was to analyze the association of Vitamin D receptor gene (VDR) polymorphisms in Mexican Mestizo patients.

Methods: A case-control study was conducted in which 107 cases with primary OA of the knee and 114 controls were included. Cases were patients $>40$ years of age with a Body mass index (BMI) of $\leq 27$ and a radiological score for $\mathrm{OA}$ of the knee of $\geq 2$. Controls were subjects $>40$ years of age with a radiological score of $<2$. VDR polymorphisms rs1544410, rs7975232, and rs731236 were analyzed by means of restriction endonucleases, and logistic regression was developed to evaluate risk magnitude.
\end{abstract}

Results: A significantly increased risk was found of nearly two-fold for the allele T and TT genotypes of rs 731236 , independently of other well recognized risk factors.

Conclusions: The rs731236 polymorphism is associated with the risk of primary OA of the knee in Mexican Mestizo population.

Keywords: Osteoarthritis, Vitamin D receptor gene, Polymorphism, Mexican Mestizo population, Association study

\section{Background}

Osteoarthritis (OA) is the most frequent form of arthritis and is a leading cause of musculoskeletal disability worldwide. The World Health Organization (WHO) estimates that approximately $10 \%$ of the world's population aged $\geq 60$ years have symptomatic OA and that it is the fourth leading cause of Years lived with disability (YLD) $[1,2]$. OA can occur in any joint, but the knee is the most common site involved; in fact, it is considered that $6 \%$ of adults can be affected and that this is one of the most common reasons for total joint replacement [3-5]. OA is characterized by progressive degeneration of articular cartilage in synovial joints, resulting in joint

\footnotetext{
* Correspondence: fovi01@prodigy.net.mx

'Departments of Genetics, Instituto Nacional de Rehabilitación "Luis Guillermo Ibarra Ibarra", Calzada México-Xochimilco No. 289, Arenal Guadalupe, Tlalpan, CP 14389 México City, Mexico

Full list of author information is available at the end of the article
}

space narrowing, osteophyte formation, and subchondral sclerosis, which is clinically translated as pain and joint stiffness $[4,5]$.

$\mathrm{OA}$ is a multifactorial disease in which genetics and environmental factors, such as aging, gender, obesity, significant trauma, occupation, and sports activities, among others, are strongly related with its development $[4,5]$. It is classified as primary when no discernible cause is evident and secondary when a triggering factor is apparent. Primary OA possess a strong genetic component, as demonstrated by several twin and family studies, which have demonstrated $39-65 \%$ heritability $\left(\mathrm{h}^{2}\right)$ and an increased risk for OA of up to 14-fold in first-degree relatives of probands with OA [6, 7]. On the other hand, genetic association studies have demonstrated that primary $\mathrm{OA}$ is associated with several genes related to different molecular pathways or classes of molecules such as inflammation, Extracellular matrix 
(ECM) molecules, Wnt signaling, Bone morphogenetic proteins, proteases or their inhibitors, and genes related with modulation of osteocyte or chondrocyte differentiation $[6,7]$.

The Vitamin D receptor plays an important role in skeletal metabolism because this acts as an important regulator of calcium metabolism and bone cell function; therefore, its abnormalities are probably related with OA [8]. The vitamin D receptor gene (VDR) is located on chromosome 12q13.11, contains 11 exons, and spans approximately $75 \mathrm{~kb}$. The gene contains several polymorphisms, and three have been frequently studied for determining an association in OA: rs1544410 and rs7975232 in intron 8, and the synonymous variant rs731236 in exon 9 [9-11]. With regard to primary OA of the knee, some reports have shown an association in the presence of these $V D R$ polymorphisms [12-14], however, this has not always been confirmed [15-18]. A meta-analysis on the three most frequently studied $V D R$ polymorphisms in OA analyzed Asian and European studies; however, the results showed no association in all study subjects, as well as by stratification by ethnicity [19]. An updated meta-analysis, showed a significant association between the A allele and AA genotype of the rs7975232 with OA in Asian population, but not in the whole population [20]. Because genetic associations could vary among populations and because there are no association studies on VDR and OA in Latin-American populations, our aim was to analyze the association of the three $V D R$ polymorphisms in Mexican Mestizo patients.

\section{Methods}

\section{Subjects}

We conducted a case-control study whose protocol was approved by the Ethics and Investigation Committee of the National Rehabilitation Institute, a tertiary-care referral center in Mexico City. All of the participants were recruited at the Articular Rehabilitation Clinic and were of Mexican Mestizo origin, the latter defined as a person born in Mexico, with a Spanish-derived last name, and with a family of Mexican ancestors back to the third generation [21]. Cases included persons aged $>40$ years with a clinical diagnosis of OA and a radiologic score of $\geq 2$ for OA of the knee, with a Body mass index (BMI, $\mathrm{kg} / \mathrm{m}^{2}$ ) of $\leq 27$, with no history of serious injuries or knee surgeries, and with no other articular diseases. Controls were subjects aged $>40$ years without a clinical diagnosis of OA of the knee, with a radiologic score of $<$ 2 , and with no history of serious knee injuries or diseases of the joints. All controls arrived at the clinic mainly due to orthopedic problems, such as shoulder lesions or fractures, or orthopedic problems not involving serious knee damage. Radiological evaluation of all participants was performed by a sole trained observer who was blinded to the patients' diagnosis. Grading of OA was assessed using a 5-point scale according to the KellgrenLawrence radiographic-classification grading method in anteroposterior weight-bearing and lateral $\mathrm{x}$-rays of the knees [22]. To perform a more efficient classification of cases and controls and to identify possible co-variables or confounders, all study subjects were interviewed by application of a questionnaire designed specifically for this study in order to collect information regarding general, occupational, and sports activities, possible knee injuries, and clinical manifestations of OA, among others.

\section{Genotyping}

After obtaining signed informed consent, a 5-ml blood sample was drawn from each patient into tubes containing EDTA. Peripheral blood mononuclear cells were isolated, and DNA was extracted utilizing a salting out method. The genotype for three polymorphisms of the $V D R$ was determined by Polymerase-chain-reaction (PCR) amplification and enzymatic digestion of the products using the primer pair listed previously [23]. The forward primer was the same for all three polymorphisms: $5^{\prime}$ CAACCAAGACTACAAGTACCGCGTCAGTGA-3'. For rs7975232 and rs731236 polymorphisms, the reverse primer was 5'-CACTTCGAGCACAAGGGGCGTTAGC-3'; and for rs1544410 was $5^{\prime}$-AACCAGCGGGAAGAGGTCAAGGG-3'. PCR was performed with a Gene Amp PCR system 9700 PE Applied Biosystems under standard conditions. Briefly, for fragment amplification 1X buffer solution was used ( $\mathrm{KCl} 50 \mathrm{mM}$, Tris- $\mathrm{HCl} 20 \mathrm{mM} \mathrm{pH} \mathrm{8.4),} 0.6 \mathrm{mM}$ DNTP, $0.5 \mu \mathrm{M}$ of each primer, $4 \mathrm{mM} \mathrm{MgCl} 2,2.5 \mathrm{U}$ Taq polymerase, and 250 ng genomic DNA, for a final volume reaction of $50 \mu \mathrm{L}$. A thermal profile was optimized as follows: $94{ }^{\circ} \mathrm{C}$ for $5 \mathrm{~min}$ for initial denaturation, followed by 28 cycles at $94{ }^{\circ} \mathrm{C}$ for $1 \mathrm{~min}$, at $65{ }^{\circ} \mathrm{C}$ for $1 \mathrm{~min}$, at $72{ }^{\circ} \mathrm{C}$ for $1 \mathrm{~min}$, and $5 \mathrm{~min}$ at $72{ }^{\circ} \mathrm{C}$ for final extension. Subsequently, one microgram of the PCR product was digested with an excess of the endonucleases under conditions specified by the supplier (New England Biolabs, Inc., Beverly, MA, USA) and was electrophoresed on $1.5 \%$ ethidium- stained agarose gels. Information of Single Nucleotide Polymorphism (SNP) and product size after digestion with endonucleases is shown in Table 1.

\section{Statistical analysis}

Comparisons of continuous variables were tested by the Student $t$ test, and corrected chi-squared statistics $\left(x^{2}\right)$ were applied for categorical variables. Uni- and multivariate nonconditional logistic regression analyses were conducted to estimate probability for developing OA, comparing genotypes as main effect; Odds ratios and $95 \%$ Confidence intervals [OR $(95 \% \mathrm{CI})]$ were reported. Alpha level was 0.05 . Hardy-Weinberg equilibrium (HWE) was assessed for $V D R$ polymorphisms by means of the chi-squared test, and the 
Table 1 Information of the three single nucleotide polymorphisms of VDR gene

\begin{tabular}{|c|c|c|c|c|c|c|c|c|}
\hline SNP & Alleles & Location & Change & Enzyme & Fragments (bp) & & $\begin{array}{l}\text { Frequencies } \\
\text { Cases, controls }\end{array}$ & HWE \\
\hline rs1544410 & $A / G$ & Intron 8 & None & Bsml & G: 650/175 & $A: 825$ & $0.615,0.576$ & $<0.05$ \\
\hline rs7975232 & $\mathrm{A} / \mathrm{C}$ & Intron 8 & None & Apal & C: $1700 / 300$ & A: 2000 & $0.528,0.500$ & $<0.05$ \\
\hline rs731236 & $\mathrm{C} / \mathrm{T}$ & Exon 9 & |le352= & Taql & C: $1800 / 200$ & T: 2000 & $0.835,0.759$ & 0.28 \\
\hline
\end{tabular}

SNP: rs numbers were taken from NCBI dbSNP (http://www.ncbi.nlm.nih.gov/SNP)

HWE $p$ value in the control group

STATA ver.10.0 statistical software package and Haplo View 4.0 were utilized for calculations.

\section{Results}

The characteristics of the study population are shown in Table 2. We observed statistically significant differences in mean age and in previous sport-activity frequency $(p=0$. 00001 and 0.004; respectively).

The SNPs rs1544410 and rs7975232 were not in HWE (Table 1) and their allelic and genotypic frequencies did not showed significant differences between the study groups (Tables 1 and 3). Only rs731236 was in HWE, and its $\mathrm{C}$ and $\mathrm{T}$ alleles showed statistically significant differences $[\mathrm{OR}(95 \% \mathrm{CI})=0.6(0.4-1.0)$ and $1.6(1.0-2.6)$; respectively]. In regard to its genotypes, $\mathrm{CT}$ genotype suggested a protective factor [OR $(95 \% \mathrm{CI})=0.5(0.3-0.9)$ ], and TT genotype exhibited an increased risk with an OR (95\%CI) of 1.96 (1.1-3.4) (Table 3). For multivariate analysis two models were constructed, and the risk trends for CT and TT genotypes were maintained when

Table 2 General characteristics of the study population

\begin{tabular}{|c|c|c|c|}
\hline & $\begin{array}{l}\text { Cases } \\
(n=107)\end{array}$ & $\begin{array}{l}\text { Controls } \\
(n=114)\end{array}$ & $p$ \\
\hline Age (mean $\pm S D$ years) & $57.6 \pm 8.9$ & $51.7 \pm 8.7$ & 0.00001 \\
\hline $\mathrm{BMI}\left(\right.$ mean $\left.\pm \mathrm{SD} \mathrm{kg} / \mathrm{m}^{2}\right)$ & $26.4 \pm 2.8$ & $25.7 \pm 3.4$ & 0.08 \\
\hline Gender, females $(n, \%)$ & $86(81.1)$ & $95(83.3)$ & 0.66 \\
\hline Smoking $(n, \%)$ & $21(26.9)$ & $11(26.83)$ & 0.9 \\
\hline Alcoholism (n, \%) & $22(28.2)$ & $10(24.4)$ & 0.6 \\
\hline \multicolumn{4}{|l|}{ Occupational activity (n, \%) } \\
\hline Current $(n, \%)$ & $9(8.4)$ & $11(9.6)$ & 0.7 \\
\hline Previous $(n, \%)$ & $11(10.3)$ & $14(12.3)$ & 0.6 \\
\hline \multicolumn{4}{|l|}{ Sports activity } \\
\hline Current $(n, \%)$ & $18(16.8)$ & $29(25.4)$ & 0.12 \\
\hline Previous ( $n, \%)$ & $51(47.7)$ & $76(66.7)$ & 0.004 \\
\hline \multicolumn{4}{|l|}{ Kellgren-Lawrence grading } \\
\hline Grade 0, n (\%) & 0 & $70(61.4)$ & \\
\hline Grade 1, n (\%) & 0 & $44(38.6)$ & \\
\hline Grade 2, n (\%) & $38(35.5)$ & 0 & \\
\hline Grade 3, n (\%) & $46(42.9)$ & 0 & \\
\hline Grade 4, n (\%) & $23(21.5)$ & 0 & \\
\hline
\end{tabular}

these results were adjusted for gender, age, BMI, and previous sport activity (Table 4).

\section{Discussion}

VDR polymorphisms are probably among those most studied for a genetic association in OA; however, there is no consistency in the results [12-18]. Even in the metaanalyses, there is no agreement in their findings $[19,20]$. Those studies could entertain some limitations, because of the absence of analysis by OA site, since it is important to

Table 3 Allelic and genotype association testing results of rs1544410, rs7975232, and rs731236 in VDR for Mexican cases with osteoarthritis of the knee and controls

\begin{tabular}{cllll}
\hline SNP & $\begin{array}{l}\text { Cases } \\
(n=107) \\
n(\%)\end{array}$ & $\begin{array}{l}\text { Controls } \\
(n=114) \\
n(\%)\end{array}$ & OR (Cl 95\%) & $p$ \\
\hline $\begin{array}{c}\text { rs1544410 } \\
\text { Allele }\end{array}$ & & & & \\
A & $82(38.0)$ & $97(43.0)$ & $0.8(0.6-1.2)$ & 0.4 \\
G & $132(62.0)$ & $131(57.0)$ & $1.1(0.8-1.8)$ & 0.4 \\
Genotype & & & & \\
AA & $4(3.7)$ & $9(7.9)$ & $0.4(0.1-1.5)$ & 0.2 \\
GA & $74(69.2)$ & $79(69.3)$ & $0.9(0.5-1.8)$ & 0.9 \\
GG & $29(27.1)$ & $26(22.8)$ & $1.2(0.6-2.3)$ & 0.5
\end{tabular}

rs7975232

Allele

$$
\text { G }
$$

$T$

$112(52.0)$

$115(50.0)$

$1.1(0.7-1.6)$

0.7

$102(48.0)$

$113(50.0)$

$0.9(0.6-1.4)$

Genotype

$\begin{array}{lllll}\text { GG } & 17(15.9) & 16(14.0) & 1.1(0.5-2.4) & 0.7 \\ \text { GT } & 78(72.9) & 83(72.8) & 1.0(0.5-1.8) & 0.9 \\ \pi & 12(11.2) & 15(13.2) & 0.8(0.3-1.9) & 0.7\end{array}$

rs731236

Allele

$\begin{array}{lllll}\text { C } & 35(16.0) & 55(24.0) & 0.6(0.4-1.0) & 0.04\end{array}$

$\begin{array}{lllll}T & 179(84.0) & 173(76.0) & 1.6(1.0-2.6) & 0.04\end{array}$

Genotype

$\begin{array}{lllll}\text { CC } & 3(2.8) & 3(2.6) & 1.1(0.2-5.4) & 0.9\end{array}$

$\begin{array}{lllll}C T & 29(27.1) & 49(42.9) & 0.5(0.3-0.9) & 0.01\end{array}$

$\begin{array}{lllll}\pi & 75(70.1) & 62(54.4) & 1.9(1.1-3.4) & 0.02\end{array}$

anadjusted Odds ratios and 95\% Confidence intervals [OR $(95 \% \mathrm{Cl})]$ 
Table 4 Multivariate analysis results of rs731236 for Mexican cases with osteoarthritis of the knee and controls

\begin{tabular}{lllll}
\hline Genotype & OR $(C \mid 95 \%)^{\mathrm{a}}$ & $p$ & $\mathrm{OR}(\mathrm{Cl} 95 \%)^{\mathrm{b}}$ & $p$ \\
\hline $\mathrm{CC}$ & $0.9(0.1-6.0)$ & 0.9 & $1.1(0.2-6.7)$ & 0.9 \\
$\mathrm{CT}$ & $0.5(0.3-0.9)$ & 0.03 & $0.5(0.3-0.9)$ & 0.03 \\
$\Pi \mathrm{T}$ & $1.9(1.1-3.4)$ & 0.03 & $1.8(1.02-3.3)$ & 0.04 \\
\hline
\end{tabular}

adjusted by gender, age, BMI

badjusted by gender, age, BMI, previous sport activities

consider that associations in OA appear to be jointspecific, as suggested by association studies [6, 24] and supported by functional analyses [25]. Therefore, the genetic associations in OA of the knee should be analyzed independently of other anatomic sites. Our findings suggest that there is an association between the rs731236 polymorphism and knee OA in this Mexican Mestizo population, conferring an increased risk of nearly two-fold in the presence of T allele and TT genotype independently of other well recognized risk factors such as age, gender, BMI, and sport activities.

The rs731236 is a synonymous polymorphism located in the coding sequence and exerts no effect in the encoded protein $[10,11]$. However, a functional effect of this polymorphism is suggested by studies in which homozygous TT were associated with low VDR messenger RNA (mRNA) levels, and with low serum vitamin D level in some types of cancer [26, 27]. Interestingly, Subjects with low serum levels of vitamin D had a 3-fold increased risk for progression of OA of the knee [28]. Moreover, the activity of Matrix metalloproteinases (MMP) in the growth plate chondrocyte is regulated by vitamin D [29], and low levels of vitamin D increase MMP activities [30], which contributes to cartilage degradation, the hallmark in OA $[4,5]$.

On the other hand, it is possible that the rs731236 reflects a real association with other genes located in the same chromosomal region, such as Collagen type II alpha 1 chain (COL2A1), which is localized at a distance of $20 \mathrm{~kb}$ upstream [31]. Indeed, previously an association of COL $2 A 1$ polymorphisms with knee OA was observed [32]. Or Histone deacetylase 7 (HADC7), at $10 \mathrm{~kb}$ downstream, which although there are not association studies with $H D A C 7$ polymorphisms, its increased expression in the cartilage of patients with OA suggests that it may contribute to cartilage degradation [33].

$V D R$ polymorphisms have been analyzed in different ethnic groups and differences in allele frequencies have been noted [11]; this could be due to population stratification and could explain the inconsistency in the results. For case-control genetic-association studies, this is a matter of concern because it has been suggested that the existence of genetic subgroups in a population may lead to spurious associations [34]. To control this genetic confounder, ancestry informative markers are suggested to be analyzed to avoid bias [35]. Mexican Mestizos are an admixed population [36], therefore, a possible weakness in this work is that ethnicity was determined only by self-reported family ancestry and by family history. However, the degree to which population stratification has caused confounding remains controversial [37, 38], and it has been suggested that this should not be a major confounder and that self-reported ethnicity may be sufficient to resolve that bias [38, 39]. In fact, it have been demonstrated that self-identified ethnicity correlate well with ancestral markers [40, 41]. Additionally, it is also important to consider that our controls were originated from the same geographic regions of the country as that of cases, and that the allele associated with primary OA of the knee follows HWE. This may indicate that allele frequency is not affected by inbreeding, mutation, natural selection, migration, or even population stratification [42]. Thus, spurious associations resulting from the presence of genetically different strata in our study sample are unlikely.

We are aware that being a hospital-based casecontrol study, it is exposed to incurring in selection bias. Therefore, to assess cases with primary OA of the knee as close as possible, the variables considerably associated with the development of secondary OA were strictly controlled during study-subject recruitment. Therefore, we think that the possibility of selection bias in our sample is low. Additionally, other potential confounders were controlled during statistical analyses, through multivariate analysis because this protects against population structure and limits the number of false positives [43]. In that sense, variables with significant differences during univariate analysis did not exhibit an effect on risk magnitude during multivariate analysis.

We recognize that our main limitation comprises sample size. However, we attempted to increase our internal validity by strictly controlling possible confounder variables through selection criteria and multivariate analysis, and we consider that our cases are truly primary OA of the knees. Finally, it is important to consider that association studies in diverse ethnic groups worldwide, especially those with a complex admixture of ancestral populations such as Latin-American populations, are a powerful resource for analyzing the genetic bases of complex diseases [44]; therefore, genetic association studies in Latino Americans would provide a better appreciation of the genetic contributions to primary OA.

\section{Conclusions}

According to the findings of this study, the rs731236 polymorphism is associated with the risk of primary OA of the knee in Mexican Mestizo population. 


\section{Abbreviations}

BMl: Body mass index; COL2A1: Collagen type II alpha 1 chain gene; ECM: Extracellular matrix; HADC7: Histone deacetylase 7 gene; HWE: HardyWeinberg equilibrium; MMP: Matrix metalloproteinases; mRNA: messenger RNA; OA: Osteoarthritis; OR (95\% Cl): Odds ratios (95\% Confidence intervals); PCR: Polymerase-chain-reaction; SNP: Single Nucleotide Polymorphism; VDR: Vitamin D receptor gene; WHO: World Health Organization; YLD: Years lived with disability

\section{Authors' contributions}

Concept and Study design: NCG-H, VMB-C and AM-D. Data acquisition: NCG-H, VMB-C, EM-H, CD-S. Data analysis, manuscript preparation: AM-D. All authors read and approved the final manuscript.

\section{Competing interests}

The authors declare that they have no competing interests.

\section{Publisher's Note}

Springer Nature remains neutral with regard to jurisdictional claims in published maps and institutional affiliations.

\section{Author details}

'Departments of Genetics, Instituto Nacional de Rehabilitación "Luis Guillermo Ibarra Ibarra", Calzada México-Xochimilco No. 289, Arenal Guadalupe, Tlalpan, CP 14389 México City, Mexico. ²Departments of Radiology, Instituto Nacional de Rehabilitación "Luis Guillermo Ibarra Ibarra", Calzada México-Xochimilco No. 289, Arenal Guadalupe, Tlalpan, CP 14389 México City, Mexico. ${ }^{3}$ Departments of Rheumatology, Instituto Nacional de Rehabilitación "Luis Guillermo Ibarra Ibarra", Calzada México-Xochimilco No. 289, Arenal Guadalupe, Tlalpan, CP 14389 México City, Mexico.

\section{Received: 26 February 2018 Accepted: 29 March 2018}

\section{Published online: 24 May 2018}

\section{References}

1. Woolf AD, Pfleger B. Burden of major musculoskeletal conditions. Bull World Health Organ. 2003:81:646-56.

2. Haq SA, Davatchi F. Osteoarthritis of the knees in the COPCORD world. Int J Rheum Dis. 2011;14:122-9.

3. Weinstein AM, Rome BN, Reichmann WM, Collins JE, Burbine SA, Thornhill TS, et al. Estimating the burden of total knee replacement in the United States. J Bone Joint Surg Am. 2013;95:385-92.

4. Michael JW, Schlüter-Brust KU, Eysel P. The epidemiology, etiology, diagnosis, and treatment of osteoarthritis of the knee. Dtsch Arztebl Int 2010;107:152-62

5. Johnson VL, Hunter DJ. The epidemiology of osteoarthritis. Best Pract Res Clin Rheumatol. 2014;28:5-15.

6. Valdes AM, Spector TD. Genetic epidemiology of hip and knee osteoarthritis. Nat Rev Rheumatol. 2011;7:23-32.

7. Loughlin J. Genetic contribution to osteoarthritis development: current state of evidence. Curr Opin Rheumatol. 2015;27:284-8.

8. Colombini A, Cauci S, Lombardi G, Lanteri P, Croiset S, Brayda-Bruno M, et al. Relationship between vitamin D receptor gene (VDR) polymorphisms, vitamin D status, osteoarthritis and intervertebral disc degeneration. J Steroid Biochem Mol Biol. 2013:138:24-40.

9. Baker AR, McDonnell DP, Hughes M, Crisp TM, Mangelsdorf DJ, Haussler MR, et al. Cloning and expression of full-length cDNA encoding human vitamin D receptor. Proc Natl Acad Sci U S A. 1988;85:3294-8.

10. Miyamoto K, Kesterson RA, Yamamoto H, Taketani Y, Nishiwaki E, Tatsumi S, et al. Structural organization of the human vitamin D receptor chromosomal gene and its promoter. Mol Endocrinol. 1997;11:1165-79.

11. Uitterlinden AG, Fang Y, Van Meurs JB, Pols HA, Van Leeuwen JP. Genetics and biology of vitamin D receptor polymorphisms. Gene. 2004:338:143-56.

12. Uitterlinden $A G$, Burger $H$, Huang $Q$, Odding $E$, Duijn CM, Hofman $A$, et al. Vitamin $D$ receptor genotype is associated with radiographic osteoarthritis at the knee. J Clin Invest. 1997:100:259-63.

13. Keen RW, Hart DJ, Lanchbury JS, Spector TD. Association of early osteoarthritis of the knee with a Taq I polymorphism of the vitamin D receptor gene. Arthritis Rheum. 1997:40:1444-9.

14. Uitterlinden $\mathrm{AG}$, Burger $\mathrm{H}$, van Duijn $\mathrm{CM}$, Huang $\mathrm{Q}$, Hofman A, Birkenhäger $J$ C, et al. Adjacent genes, for COL2A1 and the vitamin D receptor, are associated with separate features of radiographic osteoarthritis of the knee. Arthritis Rheum. 2000:43:1456-64.

15. Loughlin J, Sinsheimer JS, Mustafa Z, Carr AJ, Clipsham K, Bloomfield VA, et al. Association analysis of the vitamin $\mathrm{D}$ receptor gene, the type collagen gene COL1A1, and the estrogen receptor gene in idiopathic osteoarthritis. J Rheumatol. 2000;27:779-84.

16. Huang J, Ushiyama T, Inoue K, Kawasaki T, Hukuda S. Vitamin D receptor gene polymorphisms and osteoarthritis of the hand, hip, and knee: a casecontrol study in Japan. Rheumatology. 2000;39:79-84.

17. Baldwin CT, Cupples LA, Joost O, Demissie S, Chaisson C, Mcalindon T, et al. Absence of linkage or association for osteoarthritis with the vitamin D receptor/type II collagen locus: the Framingham Osteoarthritis Study. J Rheumatol. 2002:29:161-5.

18. Muraki S, Dennison E, Jameson K, Boucher BJ, Akune T, Yoshimura N, et al. Association of vitamin D status with knee pain and radiographic knee osteoarthritis. Osteoarthr Cartil. 2011;19:1301-6.

19. Lee $\mathrm{YH}$, Woo JH, Choi SJ, Ji JD, Song GG. Vitamin D receptor Taql, Bsml and Apal polymorphisms and osteoarthritis susceptibility: a meta-analysis. Joint Bone Spine. 2009:76:156-61.

20. Zhu ZH, Jin XZ, Zhang W, Chen M, Ye DQ, Zhai Y, et al. Associations between vitamin $D$ receptor gene polymorphisms and osteoarthritis: an updated meta-analysis. Rheumatology. 2014;53:998-1008.

21. Gorodezky C, Aláez C, Vázquez-García MN, de la Rosa G, Infante E, Balladares $\mathrm{S}$, et al. The genetic structure of Mexican Mestizos of different locations: tracking back their origins through $\mathrm{MHC}$ genes, blood group systems, and microsatellites. Hum Immunol. 2001;62:979-91.

22. Kellgren JH, Lawrence JS. Radiological assessment of osteo-arthrosis. Ann Rheum Dis. 1957:16:494-502

23. Yokoyama K, Shigematsu T, Tsukada T, Ogura Y, Takemoto F, Hara S, et al. Apa I polymorphism in the vitamin D receptor gene may affect the parathyroid response in Japanese with end-stage renal disease. Kidney Int 1998;53:454-8.

24. Reynard LN, Loughlin J. The genetics and functional analysis of primary osteoarthritis susceptibility. Expert Rev Mol Med. 2013;15:e2.

25. Xu Y, Barter MJ, Swan DC, Rankin KS, Rowan AD, Santibanez-Koref M, et al. Identification of the pathogenic pathways in osteoarthritic hip cartilage: commonality and discord between hip and knee OA. Osteoarthr Cartilage. 2012;20:1029-38.

26. Carling T, Rastad J, Åkerström G, Westin G. Vitamin D receptor (VDR) and parathyroid hormone messenger ribonucleic acid levels correspond to polymorphic VDR alleles in human parathyroid tumors. J Clin Endocrinol Metab. 1998;83:2255-9.

27. Yaylim-Eraltan I, Arzu Ergen H, Arikan S, Okay E, Oztürk O, Bayrak S, et al. Investigation of the VDR gene polymorphisms association with susceptibility to colorectal cancer. Cell Biochem Funct. 2007:25:731-7.

28. McAlindon TE, Felson DT, Zhang Y, Hannan MT, Aliabadi P, Weissman B, et al. Relation of dietary intake and serum levels of vitamin $D$ to progression of osteoarthritis of the knee among participants in the Framingham study. Ann Intern Med. 1996:125:353-9.

29. Boyan BD, Schwartz Z. 1,25-Dihydroxy vitamin D3 is an autocrine regulator of extracellular matrix turnover and growth factor release via ERp60activated matrix vesicle matrix metalloproteinases. Cells Tissues Organs. 2009:189:70-4.

30. Dean DD, Schwartz Z, Schmitz J, Muniz OE, Lu Y, Calderon F, et al. Vitamin $D$ regulation of metalloproteinase activity in matrix vesicles. Connect Tissue Res. 1996:35:331-6.

31. Fang $Y$, van Meurs JB, d'Alesio A, et al. Promoter and 3'-untranslated-region haplotypes in the vitamin d receptor gene predispose to osteoporotic fracture: the Rotterdam study. Am J Hum Genet. 2005;77:807-23.

32. Gálvez-Rosas A, González-Huerta C, Borgonio-Cuadra VM, DuarteSalazár C, Lara-Alvarado L, de los Angeles Soria-Bastida M, et al. A COL2A1 gene polymorphism is related with advanced stages of osteoarthritis of the knee in Mexican Mestizo population. Rheumatol Int. 2010:30:1035-9.

33. Higashiyama R, Miyaki S, Yamashita S, Yoshitaka T, Lindman G, Ito Y, et al. Correlation between MMP-13 and HDAC7 expression in human knee osteoarthritis. Mod Rheumatol. 2010;20:11-7.

34. Lander ES, Schork NJ. Genetic dissection of complex traits. Science. 1994. 265:2037-48.

35. Cardon $L R$, Palmer $\perp$. Population stratification and spurious allelic association. Lancet. 2003;361:598-604. 
36. Moreno-Estrada A, Gignoux CR, Fernández-López JC, Zakharia F, Sikora M, Contreras AV, et al. Human genetics. The genetics of Mexico recapitulates native American substructure and affects biomedical traits. Science. 2014; 344:1280-5.

37. Thomas DC, Witte JS. Point: population stratification: a problem for casecontrol studies of candidate-gene associations? Cancer Epidemiol Biomark Prev. 2002;11:505-12.

38. Wacholder S, Rothman N, Caporaso N. Counterpoint: bias from population stratification is not a major threat to the validity of conclusions from epidemiological studies of common polymorphisms and cancer. Cancer Epidemiol Biomark Prev. 2002;11:513-20.

39. Barnholtz-Sloan JS, McEvoy B, Shriver MD, Rebbeck TR. Ancestry estimation and correction for population stratification in molecular epidemiologic association studies. Cancer Epidemiol Biomark Prev. 2008;17:471-7.

40. Tang H, Quertermous T, Rodríguez B, Kardia SL, Zhu X, Brown A, et al. Genetic structure, self identified race/ethnicity, and confounding in casecontrol association studies. Am J Hum Genet. 2005;76:268-75.

41. Yaeger R, Ávila-Bront A, Abdul K, Nolan PC, Grann VR, Birchette MG, et al. Comparing genetic ancestry and self-described race in African Americans born in the United States and in Africa. Cancer Epidemiol Biomark Prev. 2008;17:1329-38.

42. Rodríguez S, Gaunt TR, Day IN. Hardy-Weinberg equilibrium testing of biological ascertainment for Mendelian randomization studies. Am J Epidemiol. 2009;169:505-14.

43. Setakis $E$, Stirnadel $H$, Balding DJ. Logistic regression protects against population structure in genetic association studies. Genome Res. 2006; 16:290-6.

44. González-Burchard E, Borrell LN, Choudhry S, Naqvi M, Tsai HJ, RodriguezSantana JR, et al. Latino populations: a unique opportunity for the study of race, genetics, and social environment in epidemiological research. Am J Public Health. 2005;95:2161-8.

Ready to submit your research? Choose BMC and benefit from:

- fast, convenient online submission

- thorough peer review by experienced researchers in your field

- rapid publication on acceptance

- support for research data, including large and complex data types

- gold Open Access which fosters wider collaboration and increased citations

- maximum visibility for your research: over $100 \mathrm{M}$ website views per year

At BMC, research is always in progress.

Learn more biomedcentral.com/submissions 